\title{
UFLC-PDA-MS/MS Profiling of Seven Uncaria Species Integrated with Melatonin/5-Hydroxytryptamine Receptors Agonistic Assay
}

\author{
Jian-Gang Zhang ${ }^{1} \cdot$ Xiao-Yan Huang ${ }^{1} \cdot$ Yun-Bao Ma ${ }^{1} \cdot$ Ji-Jun Chen $^{1,2} \cdot$ Chang-An Geng $^{1}[$
}

Received: 5 December 2019 / Accepted: 6 January 2020 / Published online: 13 January 2020

(c) The Author(s) 2020

\begin{abstract}
Uncariae Ramulus Cum Uncis (Gou-Teng), the dried hook-bearing stems of several Uncaria plants (Rubiaceae), is a wellknown herbal medicine in China. The clinical application of Gou-Teng is bewildered for the morphological and chemical similarity between different species. In order to discern their chemical and biological difference, an ultra-fast liquid chromatography equipped with ion trap time-of-flight mass spectrometry (UFLC-IT/TOF-MS) combining with melatonin $\left(\mathrm{MT}_{1}\right.$ and $\left.\mathrm{MT}_{2}\right)$ and 5-hydroxytryptamine (5- $\mathrm{HT}_{1 \mathrm{~A}}$ and 5- $\left.\mathrm{HT}_{2 \mathrm{C}}\right)$ receptors agonistic assay in vitro was conducted on seven Uncaria species. As a result, 57 compounds including 35 indole alkaloids, ten flavonoids, five triterpenoids, five chlorogenic analogues, and two other compounds were characterized based on their MS/MS patterns and UV absorptions. Specifically, cadambine-type and corynanthein-type alkaloids were exclusively present in U. rhynchophylla and U. scandens, whereas corynoxine-type alkaloids were commonly detected in all the seven Uncaria plants. Three Uncaria species, U. rhynchophylla, U. macrophylla, and U. yunnanensis showed obviously agnostic activity on four neurotransmitter receptors $\left(\mathrm{MT}_{1}\right.$, $\mathrm{MT}_{2}, 5-\mathrm{HT}_{1 \mathrm{~A}}$, and 5-HT $2 \mathrm{C}$ ). This first-time UFLCMS-IT-TOF analyses integrated with biological assay on seven Uncaria plants will provide scientific viewpoints for the clinical application of Gou-Teng.
\end{abstract}

We dedicate this paper to Prof. Sun Han-Dong on the occasion of his 80th birthday.

Electronic supplementary material The online version of this article (https://doi.org/10.1007/s13659-020-00230-8) contains supplementary material, which is available to authorized users.

Chang-An Geng

gengchangan@mail.kib.ac.cn

1 State Key Laboratory of Phytochemistry and Plant Resources in West China, Kunming Institute of Botany, Chinese Academy of Sciences, Yunnan Key Laboratory of Natural Medicinal Chemistry, 132\# Lanhei Road, Kunming 650201, Yunnan, People's Republic of China

2 University of Chinese Academy of Sciences, Beijing 100049, People's Republic of China 


\section{Graphic Abstract}

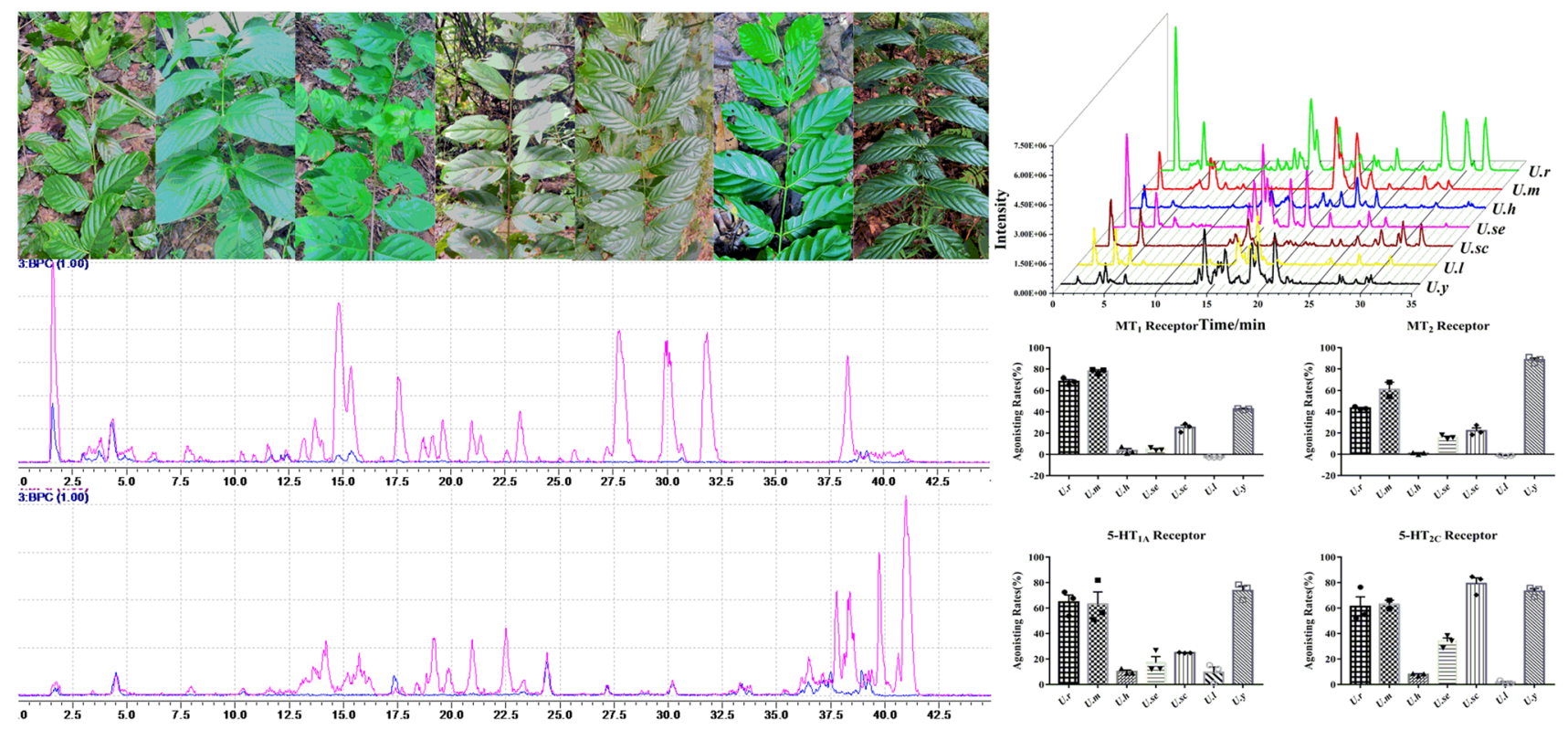

Keywords Uncariae Ramulus Cum Uncis · Uncaria plants · LCMS-IT-TOF analyses · Melatonin and 5-hydroxytryptamine receptors

\section{Introduction}

Uncariae Ramulus Cum Uncis (Gou-Teng), the dried hookbearing stems of Uncaria plants (Rubiaceae), is a wellknown traditional Chinese medicine (TCM), which has long been used for the treatment of hypertension, fever, headache, dizziness, stroke, and bilious disorders in China [1-4]. In addition to monotherapies, Gou-Teng is also prescribed in many formulae, such as Diao-Teng San (Cho-Deung-San in Korean and Choto-san in Japanese) and Yi-Gan San (Yokukansan in Japanese) [2]. Indole alkaloids as the characteristic constituents of Uncaria plants are responsible for the hypotensive effects, e.g. rhynchophylline and hirsutine showing antihypertensive and antiarrhythmic effects $[5,6]$. According to the latest Chinese Pharmacopoeia (2015 edition), five Uncaria plants, namely Uncaria rhynchophylla (U. r), Uncaria macrophylla (U. $m$ ), Uncaria sinensis (U. si), Uncaria hirsuta (U. $h$ ), and Uncaria sessilifructus ( $U$. se), are documented as the official resource of Gou-Teng [7]. Furthermore, several Uncaria plants, e.g. Uncaria scandens (U. sc), Uncaria laevigata (U. l), and Uncaria yunnanensis (U. $y$ ), are also used as the substitutes of Gou-Teng in prescriptions $[8,9]$. Although recent studies have manifested the antidepressant-like effects of $U$. rhynchophylla and $U$. lanosa, and locomotor decreasing effects of U. rhynchophylla, U. macrophylla, and U. sinensis [10-12], few reports can discern the difference regarding the chemical profiles and biological activities between different Uncaria species. Thus, the clinical application of Gou-Teng is bewildered for the morphological and chemical similarity between different Uncaria plants. Different from the cardiovascular effect, the psychiatric property and active constituents of Gou-Teng are still disputed. Melatonin (MT) and 5-hydroxytryptamine (5-HT) receptors are two types of neurotransmitter receptors closely related to mental diseases [13-16], and thus are used to evaluate the psychiatric effects of different Uncaria plants. The present study applied an ultra-fast liquid chromatography equipped with ion trap time-of-flight mass spectrometry (UFLC-IT/TOF-MS) and combined with melatonin and 5-hydroxytryptamine receptors agonistic assay to discern seven Uncaria species regarding their chemical profiles and psychiatric properties.

\section{Results and Discussions}

\subsection{LCMS-PDA Analyses}

Seven Uncaria plants were analyzed by UFLC-PDA-MS/ MS to provide their respective base peak chromatograms (BPCs) in both positive and negative modes (Fig. 1). In total, 57 compounds including 35 indole alkaloids, ten flavonoids, five triterpenoids, five chlorogenic acids, and two 

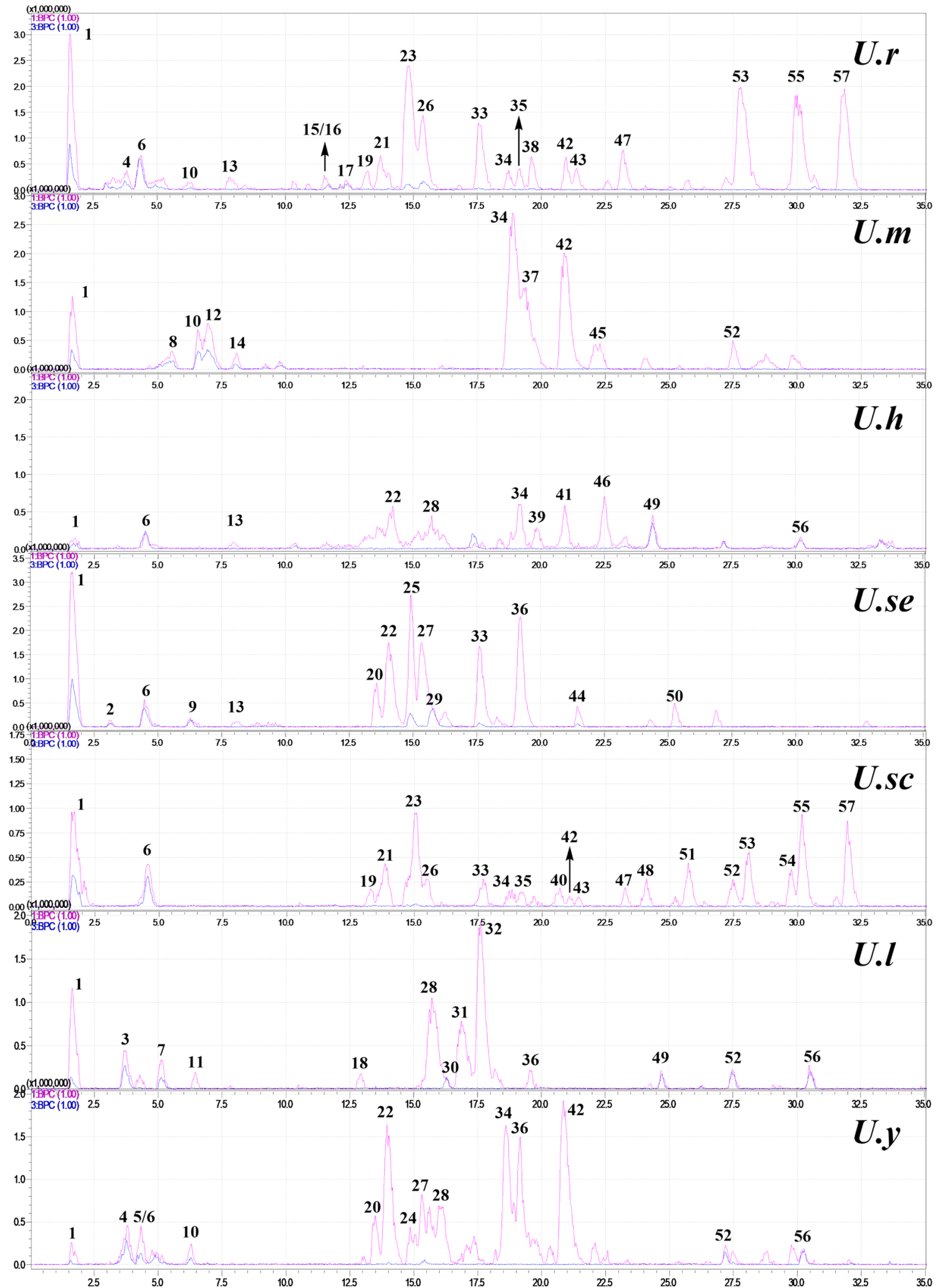

Fig. 1 Base peak chromatograms (BPCs) of seven Uncaria plants in positive (1 BPC) and negative (3 BPC) modes 
other compounds were characterized according to their UV absorptions, MS/MS fragmentations, retention time, and comparing with the reported compounds (Table 1).

\subsubsection{Indole Alkaloids}

Indole alkaloids are the characteristic constituents in Uncaria plants with high response in positive mode MS. In this investigation, a number of 35 indole alkaloids were described and divided into six subclasses including cadambine-type (19, 21, 23, 26, 47), vinsosamide-type (15), D-seco-type $(\mathbf{1 8}, \mathbf{2 5}, \mathbf{3 3}, \mathbf{3 8}, \mathbf{4 4}, \mathbf{5 0})$, corynoxine-type (11, $20,22,24,27,28,31,32,34,35,36,37,42)$, corynantheintype $(40,43,45,48,51,53,55,57)$, and ajmalicine-type $(\mathbf{3 9}, \mathbf{5 4})$. In accordance with the previous investigation [17], D-seco alkaloids commonly generated the characteristic fragmentation ions ascribed to the loss of $17 \mathrm{Da}\left(\mathrm{NH}_{3}\right)$ in the $\mathrm{MS}^{2}$ experiment; the indole and oxindole alkaloids could be differentiated from their respective maximal UV absorptions around $280 \mathrm{~nm}$ (indole) or $240 \mathrm{~nm}$ (oxindole); the numbers and types of glycosyl moieties were determined by the mass defects between the parent and fragment ions.

2.1.1.1 Cadambine-Type Alkaloids Peak 21 was identified as cadambine from the $[\mathrm{M}+\mathrm{H}]^{+}$ion at $\mathrm{m} / z, 545.2129$ with the diagnostic $\mathrm{MS}^{2}$ ions at $\mathrm{m} / \mathrm{z} 383.1612\left(\mathrm{C}_{21} \mathrm{H}_{22} \mathrm{~N}_{2} \mathrm{O}_{5}\right)$ and $351.1245\left(\mathrm{C}_{20} \mathrm{H}_{18} \mathrm{~N}_{2} \mathrm{O}_{4}\right)$, corresponding to the sequential loss of glycosyl and $\mathrm{MeOH}$ moieties [18]. Peak 19 showed the loss of $17 \mathrm{Da}$ from 565 to 548, and the loss of $162 \mathrm{Da}$ from 548 to 386 , which was characteristic for the hydrated derivative of cadambine [18]. Peaks 23, 26, and 47 possessed the same molecular formula of $\mathrm{C}_{27} \mathrm{H}_{34} \mathrm{~N}_{2} \mathrm{O}_{10}$ with two more hydrogens than 21. In the $\mathrm{MS}^{2}$ spectra, the identical fragmentation at $\mathrm{m} / z 385\left(\mathrm{C}_{21} \mathrm{H}_{24} \mathrm{~N}_{2} \mathrm{O}_{5}\right)$ and $367\left(\mathrm{C}_{21} \mathrm{H}_{22} \mathrm{~N}_{2} \mathrm{O}_{4}\right)$ suggested closely related structures. In accordance with the previous reports, $3 \alpha$-dihydrocadambine, $3 \beta$-dihydrocadambine, and $3 \beta$-isodihydrocadambine were reasonably suggested [19].

2.1.1.2 Vincosamide-Type Alkaloids Peak 15 showing a molecular formula of $\mathrm{C}_{38} \mathrm{H}_{50} \mathrm{~N}_{2} \mathrm{O}_{19}$ was deduced from the $[\mathrm{M}+\mathrm{H}]^{+}$ion at $\mathrm{m} / \mathrm{z}$ 839.3054. In the positive $\mathrm{MS}^{2}$ experiment, the sequential losses of three glycosyl moieties $\left(\mathrm{C}_{6} \mathrm{H}_{10} \mathrm{O}_{5}, 162 \mathrm{Da}\right)$ suggested the presence of three glucosyl in the structure. Finally, this compound was isolated under the guidance of LCMS analysis, and identified to be 2 '- $O$-[ $\beta$-D-glucopyranosyl- $(1 \rightarrow 6)$ - $\beta$-D-glucopyranosyl]- 11 hydroxyvincosamide based on rigid $1 \mathrm{D}$ and $2 \mathrm{D}$ NMR spectroscopic data [20].

2.1.1.3 D-seco Indole Alkaloids D-seco indole alkaloids can be well recognized from the diagnostic $\mathrm{MS}^{2}$ ions attributed to the neutral loss of $17 \mathrm{Da}\left(\mathrm{NH}_{3}\right)$ from the precursor ions. Peaks $\mathbf{3 3}$ and $\mathbf{3 8}$ were assigned with the same molecular formula of $\mathrm{C}_{27} \mathrm{H}_{34} \mathrm{~N}_{2} \mathrm{O}_{9}$ from the $[\mathrm{M}+\mathrm{H}]^{+}$ ion at $\mathrm{m} / \mathrm{z}$ 531. Their similar $\mathrm{MS}^{2}$ fragmentations at $\mathrm{m} / \mathrm{z}$ $514\left(\mathrm{C}_{27} \mathrm{H}_{31} \mathrm{NO}_{9}\right)$ and $352\left(\mathrm{C}_{21} \mathrm{H}_{21} \mathrm{NO}_{4}\right)$ indicated a pair of isomers, which were generated from the cleavage of 3-epi-strictosidine and strictosidine [21]. Peak 18 with a molecular weight of 516 was deduced to be the demethylated derivative of $\mathbf{3 8}$, owing to a $\mathrm{CH}_{2}$ (14 Da) less in the molecular formula. The $\mathrm{MS}^{2}$ fragmentation ion at $\mathrm{m} / \mathrm{z}$ 338.1568 implied the successive loss of $17 \mathrm{Da}\left(\mathrm{NH}_{3}\right)$ and $162 \mathrm{Da}\left(\mathrm{C}_{6} \mathrm{H}_{10} \mathrm{O}_{5}\right)$, by which this compound was assigned as strictosidinic acid [22]. The molecular formula of 25 was determined as $\mathrm{C}_{28} \mathrm{H}_{30} \mathrm{~N}_{2} \mathrm{O}_{11}$ by the protonated ion $\left([\mathrm{M}+\mathrm{H}]^{+}\right)$at $\mathrm{m} / \mathrm{z}$ at 571.1896 and deprotonated ion $\left([\mathrm{M}-\mathrm{H}]^{-}\right)$at $m / z$ 569.1780. In the $\mathrm{MS}^{2}$ experiment, the sequential losses of $162 \mathrm{Da}\left(\mathrm{C}_{6} \mathrm{H}_{10} \mathrm{O}_{5}\right), 18 \mathrm{Da}\left(\mathrm{H}_{2} \mathrm{O}\right)$, and $14 \mathrm{Da}\left(\mathrm{CH}_{2}\right)$ was consistent with the presence of glucosyl, hydroxyl, and methoxyl groups. From the above analyses, peak 25 was tentatively assigned as desoxycordifoline that had been isolated from Chimarrhis turbinate [23]. Peaks 44 and 50 shared the molecular weight of $\mathrm{m} / \mathrm{z} 930$ and 902 , respectively, corresponding to the chemical composition of $\mathrm{C}_{44} \mathrm{H}_{54} \mathrm{~N}_{2} \mathrm{O}_{20}$ and $\mathrm{C}_{44} \mathrm{H}_{58} \mathrm{~N}_{2} \mathrm{O}_{18}$. The sequential losses of two $162 \mathrm{Da}\left(\mathrm{C}_{6} \mathrm{H}_{10} \mathrm{O}_{5}\right)$ indicated the presence of two glucosyls. Taking its UV absorption at $219 \mathrm{~nm}$ into consideration, peak $\mathbf{4 4}$ was tentatively deduced to be neonaucleoside C [24]. Similarly, peak $\mathbf{5 0}$ was attributed to be bahienoside $\mathrm{B}$ from the fragments at $\mathrm{m} / \mathrm{z}, 341.1434$ $\left(\mathrm{C}_{19} \mathrm{H}_{20} \mathrm{~N}_{2} \mathrm{O}_{4}\right)$ and $323.1406\left(\mathrm{C}_{19} \mathrm{H}_{18} \mathrm{~N}_{2} \mathrm{O}_{3}\right)$, by retrieving the compounds isolated from the same genus [25].

2.1.1.4 Corynoxine-Type Alkaloids The spirocyclic corynoxine-type alkaloids account for the largest number of indole alkaloids within Uncaria genus. Generally, this type of alkaloids can be well recognized by their UV maximum absorption at about $240 \mathrm{~nm}$ [17]. Peaks 34, 37, and $\mathbf{4 2}$ were isomers with the equal molecular formula of $\mathrm{C}_{22} \mathrm{H}_{28} \mathrm{~N}_{2} \mathrm{O}_{4}$, which were determined by the $[\mathrm{M}+\mathrm{H}]^{+}$ion at $\mathrm{m} / z$ 385. The $\mathrm{MS}^{2}$ fragments at $\mathrm{m} / \mathrm{z} 353$ and 321 were attributed to the consecutive losses of methoxyl groups. The ion at $\mathrm{m} / z 267$ indicated the loss of the $\mathrm{C}_{5}$-side chain. By comparing their relative retention time on octadecylsilyl (ODS) column, they were deduced as isorhynchophylline, corynoxine, and rhynchophylline [26]. Peaks $\mathbf{2 7}$ and $\mathbf{3 1}$ occupied the same molecular weight of 384 , corresponding to the molecular formula of $\mathrm{C}_{21} \mathrm{H}_{24} \mathrm{~N}_{2} \mathrm{O}_{5}$. Their $\mathrm{MS}^{2}$ fragments at $\mathrm{m} / \mathrm{z} 367$, 351 , and 335 accounting for the lost $\mathrm{H}_{2} \mathrm{O}$ and two additional oxygen atoms indicated an oxygenated derivative of rhynchophyllic acid. Likewise, peaks $\mathbf{2 4}$ and $\mathbf{3 5}$ were deduced as dehydro-derivatives of rhychophylline, and peak $\mathbf{1 1}$ was proposed as the demethylated derivative of rhychophylline [27]. 


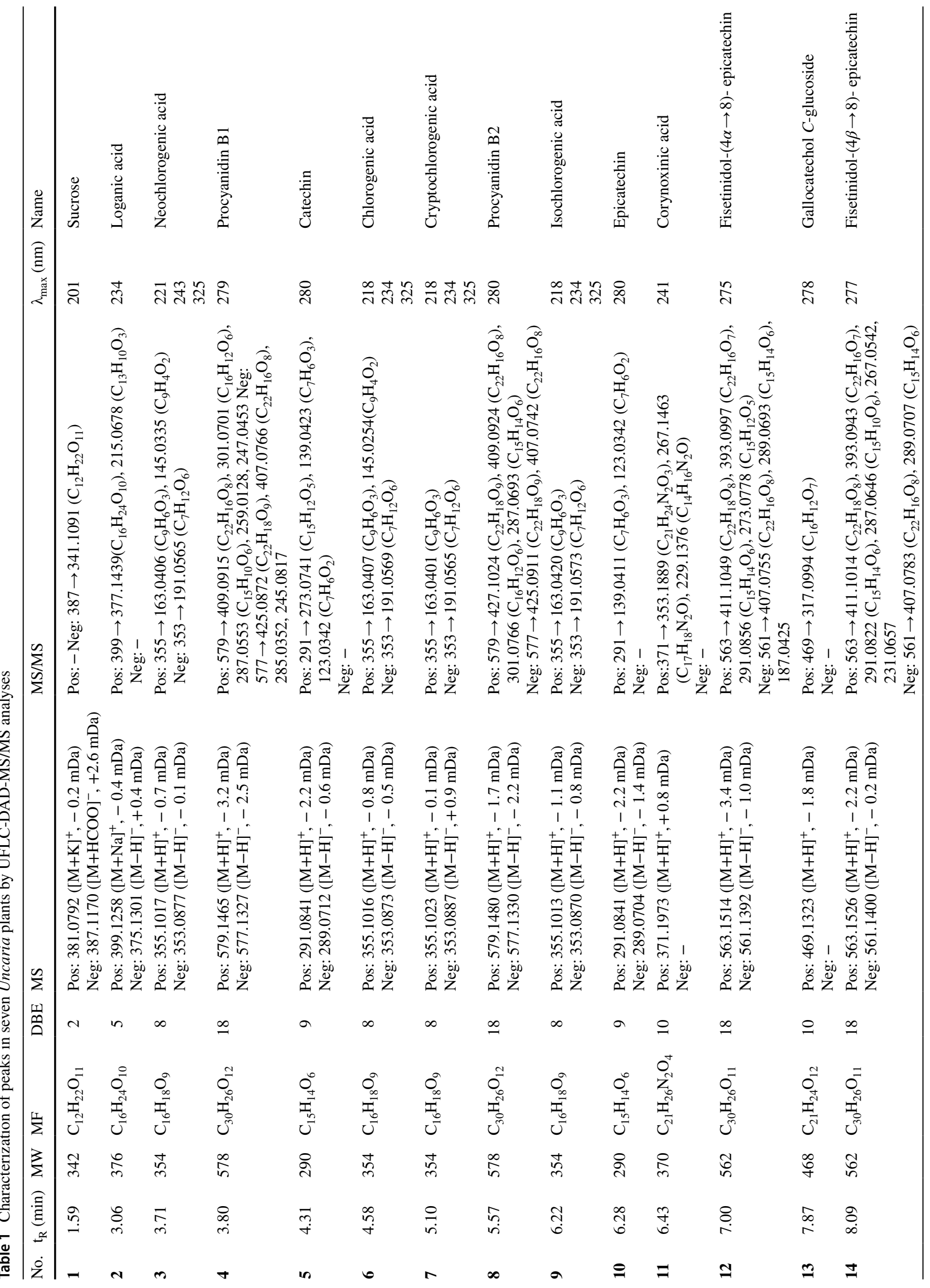




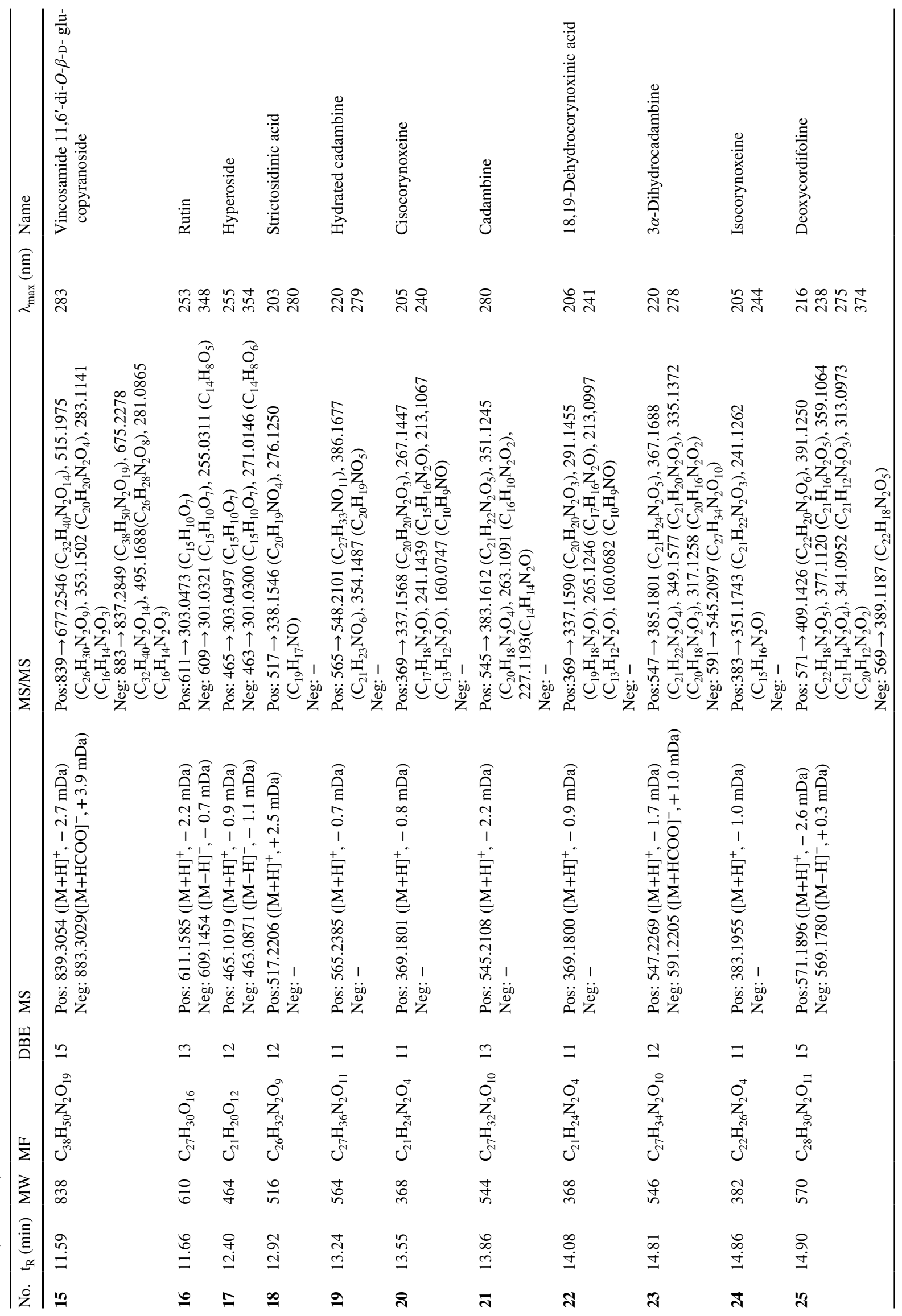




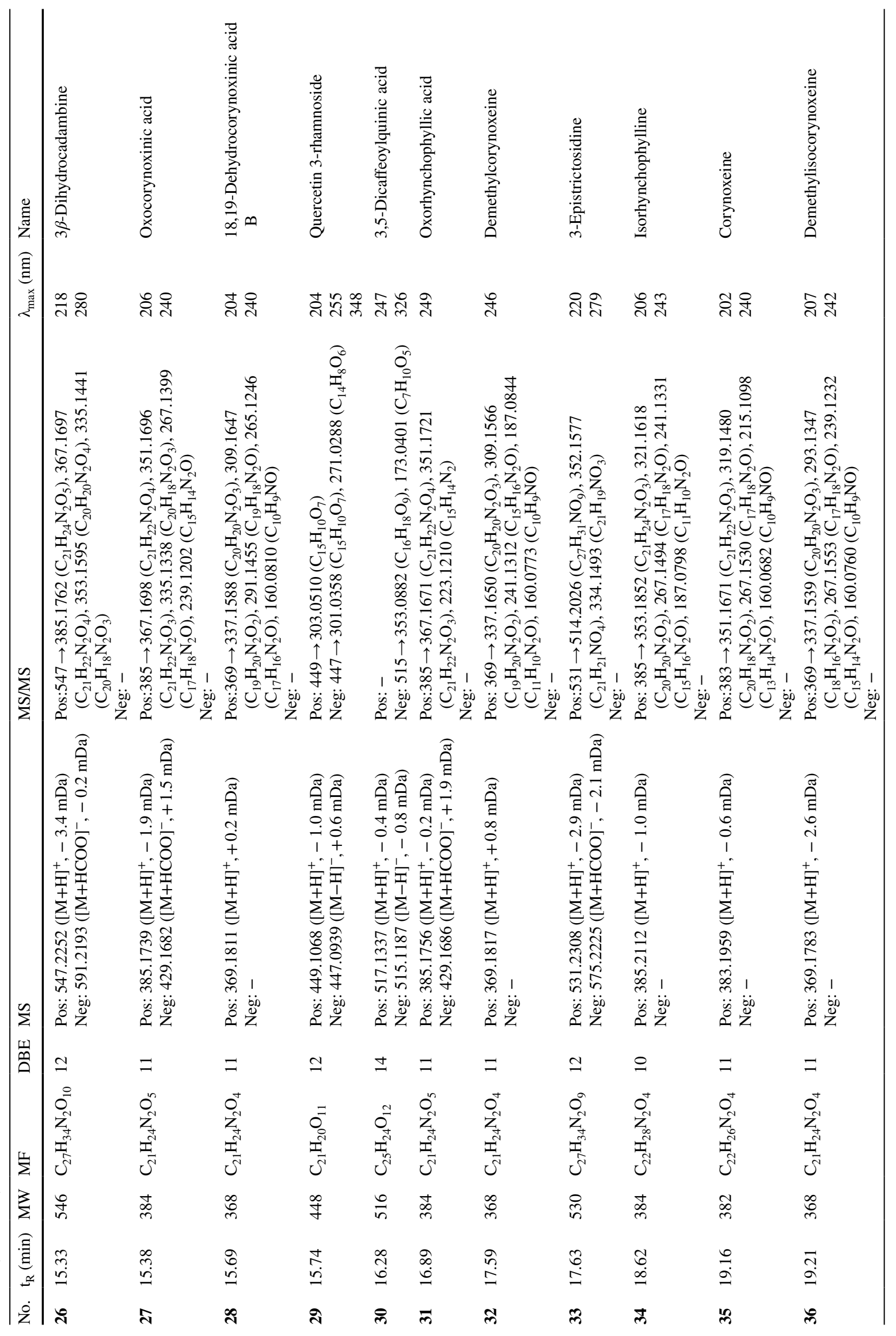




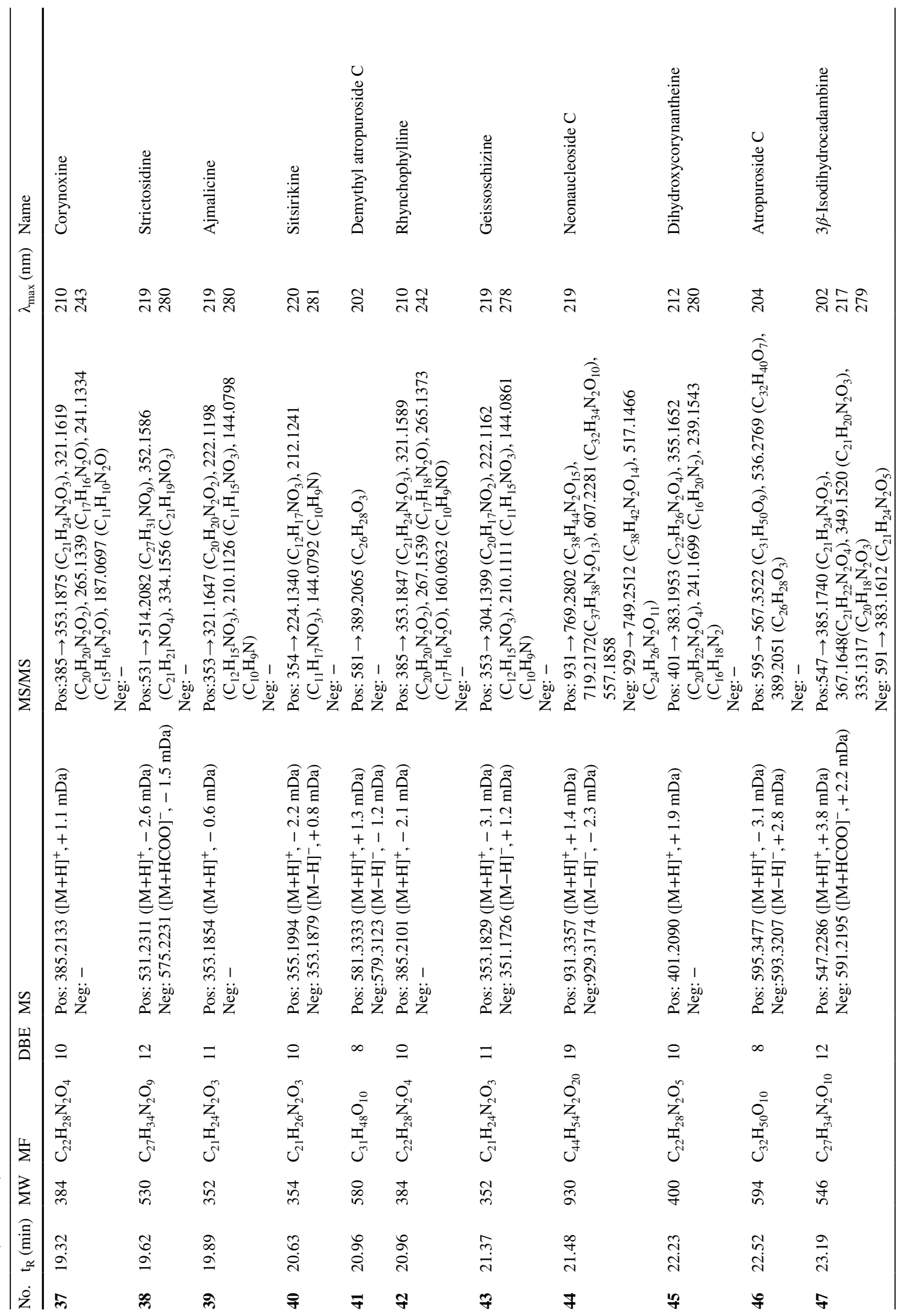




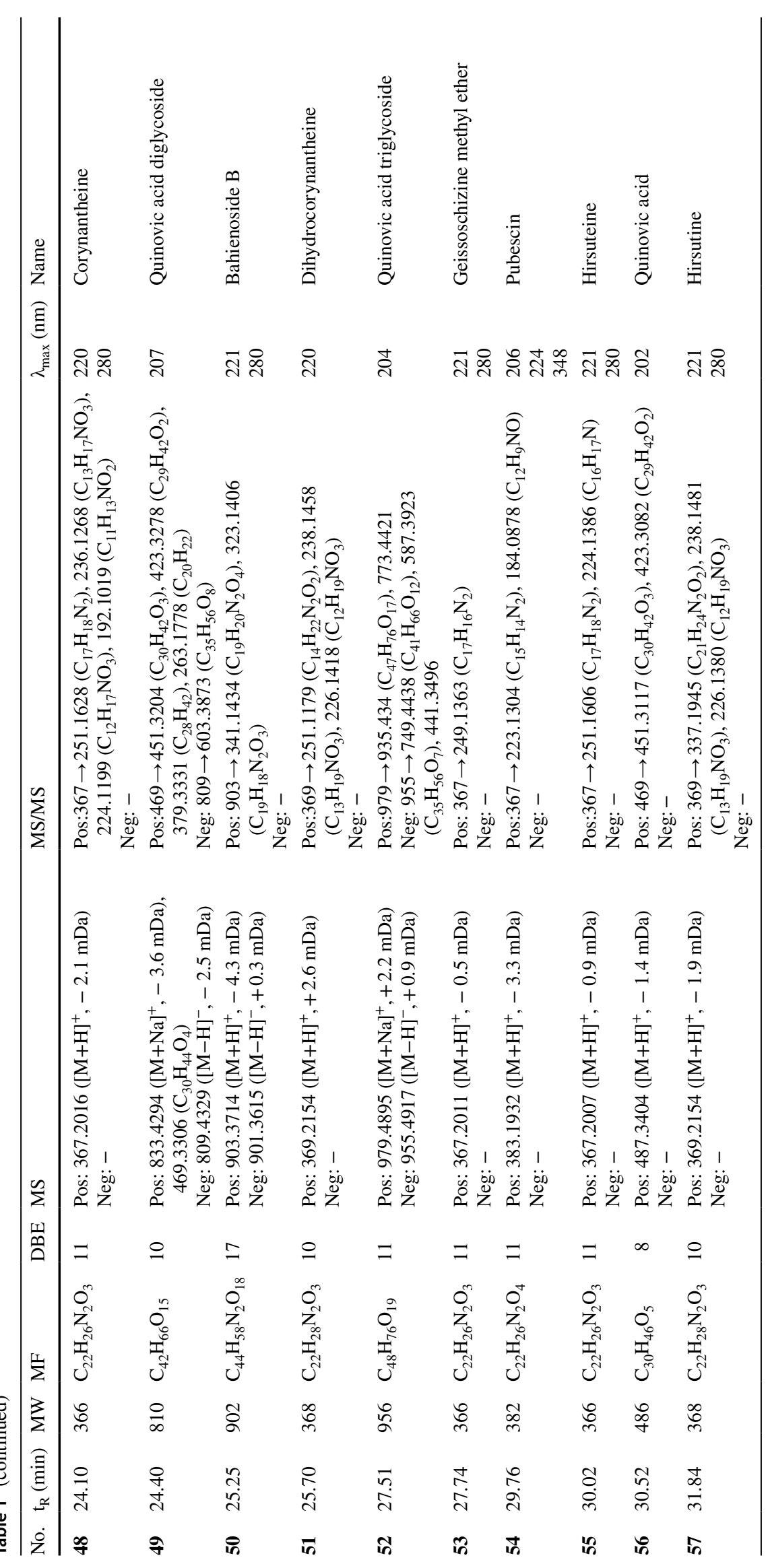


Peaks 20, 22, 28, 32, and $\mathbf{3 6}$ had the same molecular formula of $\mathrm{C}_{21} \mathrm{H}_{24} \mathrm{~N}_{2} \mathrm{O}_{4}$, with a $\mathrm{CH}_{2}$ less than corynoxeine. The $\mathrm{MS}^{2}$ fragmentation from $\mathrm{m} / \mathrm{z} 369$ to 337 verified the presence of an OMe group. The abovementioned features pointed to the demethyl corynoxeine or its isomer. The decarbonylation and decarboxylation neutral losses of $28 \mathrm{Da}$ and 46 Da were proved by the ions at $\mathrm{m} / \mathrm{z} 309$ and 291. By retrieving the corynoxine-type alkaloids isolated from this genus, the de-methyl derivates of corynoxeine, cisocorynoxeine (20), 18,19-dehydrocorynoxinic acid (22), 18,19-dehydrocorynoxinic acid B (28), demethylcorynoxeine (32), and demethylisocorynoxeine (36) were proposed [28].

2.1.1.5 Corynanthein-Type Alkaloids Peak 40 showed the protonated ion at $\mathrm{m} / \mathrm{z}$ 355.1994, indicating the molecular formula of $\mathrm{C}_{21} \mathrm{H}_{26} \mathrm{~N}_{2} \mathrm{O}_{3}$. The $\mathrm{MS}^{2}$ profiles at $\mathrm{m} / z 224.1340$ $\left(\mathrm{C}_{12} \mathrm{H}_{17} \mathrm{NO}_{3}\right), \quad 212.1241 \quad\left(\mathrm{C}_{11} \mathrm{H}_{17} \mathrm{NO}_{3}\right)$, and 144.0792 $\left(\mathrm{C}_{10} \mathrm{H}_{9} \mathrm{~N}\right)$ were indicative for sitsirikine [29]. Peaks 55 and $\mathbf{5 7}$ were assigned as hirsuteine and hirsutine, respectively, by reason of their molecular formula $\left(\mathrm{C}_{22} \mathrm{H}_{26} \mathrm{~N}_{2} \mathrm{O}_{3}\right.$ and $\mathrm{C}_{22} \mathrm{H}_{28} \mathrm{~N}_{2} \mathrm{O}_{3}$ ) and $\mathrm{MS}^{2}$ fragments. Peaks 48 and 53 with the same formula of $\mathrm{C}_{22} \mathrm{H}_{26} \mathrm{~N}_{2} \mathrm{O}_{3}$ were determined to be corynantheine and geissoschizine methyl ether following their MS $^{2}$ fragments [30]. Similarly, peaks $\mathbf{4 5}$ and $\mathbf{5 1}$ were tentatively deduced to be the dihydroxy and dihydro derivatives of corynantheine [17].

2.1.1.6 Ajmalicine-Type Alkaloids Ajmalicine-type alkaloids maintain a pentacyclic heteroyohimbines framework showing similar UV absorption with corynanthein-type alkaloids. Peaks 39 and 54 were attributed with $\mathrm{C}_{21} \mathrm{H}_{24} \mathrm{~N}_{2} \mathrm{O}_{3}$ and $\mathrm{C}_{22} \mathrm{H}_{26} \mathrm{~N}_{2} \mathrm{O}_{4}$ with 11 double bond equivalents. The mass losses from $\mathrm{m} / \mathrm{z} 352$ to $321.1647\left(\mathrm{C}_{20} \mathrm{H}_{20} \mathrm{~N}_{2} \mathrm{O}_{2}\right), 222.1198$ $\left(\mathrm{C}_{12} \mathrm{H}_{15} \mathrm{NO}_{3}\right), 210.1126\left(\mathrm{C}_{11} \mathrm{H}_{15} \mathrm{NO}_{3}\right)$, and 144.0798 $\left(\mathrm{C}_{10} \mathrm{H}_{9} \mathrm{~N}\right)$ were in agree with ajmalicine [31]. Similarly, peak 54 was reasonably deduced to be pubescin from the $\mathrm{MS}^{2}$ fragments at $m / z 223.1304\left(\mathrm{C}_{15} \mathrm{H}_{14} \mathrm{~N}_{2}\right)$ and 184.0878 $\left(\mathrm{C}_{12} \mathrm{H}_{9} \mathrm{NO}\right)$ [32].

\subsubsection{Flavonoids}

Flavonoids display characteristic UV absorptions at 220-280 (band II) and 300-400 (band I) nm, by which they can be easily characterized [33]. Peaks $\mathbf{4}$ and $\mathbf{8}$ with UV maximum absorption at $280 \mathrm{~nm}$ were designated with the molecular formula of $\mathrm{C}_{30} \mathrm{H}_{26} \mathrm{O}_{12}$ with 18 unsaturation degrees. Consequent $\mathrm{MS}^{2}$ experiment on $[\mathrm{M}+\mathrm{H}]^{+}$ion generated fragments at $m / z, 409\left(\mathrm{C}_{22} \mathrm{H}_{16} \mathrm{O}_{8}\right), 301\left(\mathrm{C}_{16} \mathrm{H}_{12} \mathrm{O}_{6}\right)$, and $287\left(\mathrm{C}_{15} \mathrm{H}_{10} \mathrm{O}_{6}\right)$ indicating flavonoids dimers. Their relative retention time on ODS column were in accordance with procyanidin b1 (4) and procyanidin b2 (8) [34]. Peaks 5 and 10 were a pair of isomers with identical molecular formula of $\mathrm{C}_{15} \mathrm{H}_{14} \mathrm{O}_{6}$. The $\mathrm{MS}^{2}$ ion at $m / z 139\left(\mathrm{C}_{7} \mathrm{H}_{6} \mathrm{O}_{3}\right)$ was ascribed to the $\mathrm{A}^{1,3}$ retrocyclization fragment on ring $\mathrm{C}$. Taking their UV absorptions at $280 \mathrm{~nm}$ and retention time into consideration, peaks $\mathbf{5}$ and $\mathbf{1 0}$ were reasonably determined as catechin (5) and epicatechin (10) [12]. Peaks 12 and 14 were isomers with the same molecular formula of $\mathrm{C}_{30} \mathrm{H}_{26} \mathrm{O}_{11}$, suggesting flavonoids dimers. The $\mathrm{MS}^{2}$ fragments at $m / z 291.0856\left(\mathrm{C}_{15} \mathrm{H}_{14} \mathrm{O}_{6}\right)$ and $273.0778\left(\mathrm{C}_{15} \mathrm{H}_{12} \mathrm{O}_{5}\right)$ were attributed to fisetinidol and catechin moieties. From the above analyses, they were tentatively deduced to be fisetinidol- $(4 \alpha \rightarrow 8)$-epicatechin and fisetinidol-( $4 \beta \rightarrow 8)$-epicatechin [35]. Peak 13 with a formula of $\mathrm{C}_{21} \mathrm{H}_{24} \mathrm{O}_{12}$ showed $\mathrm{MS}^{2}$ information at $\mathrm{m} / \mathrm{z} 317.0994$ $\left(\mathrm{C}_{16} \mathrm{H}_{12} \mathrm{O}_{7}\right)$, corresponding to the loss of a $\mathrm{C}_{5}$ part from the $C$-glycosyl moiety. From the above analyses, this peak was defined as gallocatechol $C$-glucoside [36, 37]. Peak 16 was designed with the molecular formula of $\mathrm{C}_{27} \mathrm{H}_{30} \mathrm{O}_{16}$ with an additional $\mathrm{C}_{6} \mathrm{H}_{10} \mathrm{O}_{4}$ part than $17\left(\mathrm{C}_{21} \mathrm{H}_{20} \mathrm{O}_{12}\right)$. In the $\mathrm{MS}^{2}$ experiment, the same fragments at $\mathrm{m} / \mathrm{z} 303$ in positive mode and 301 in negative mode suggested the same aglycone in 16 and 17. By retrieving the database, they were deduced as rutin (16) and hyperoside (17) [17]. Peak 29 gave [M+H] ${ }^{+}$ ion at $\mathrm{m} / \mathrm{z} 449.1068$ and $[\mathrm{M}-\mathrm{H}]^{-}$ion at $\mathrm{m} / \mathrm{z}$ 447.0939, corresponding to the molecular formula of $\mathrm{C}_{21} \mathrm{H}_{20} \mathrm{O}_{11}$. In the $\mathrm{MS}^{2}$ experiment, the diagnostic $\mathrm{MS}^{2}$ ions at $\mathrm{m} / \mathrm{z} 301.0358$ $\left(\mathrm{C}_{15} \mathrm{H}_{10} \mathrm{O}_{7}\right)$ and $271.0288\left(\mathrm{C}_{14} \mathrm{H}_{8} \mathrm{O}_{6}\right)$ in negative mode were indicative for the sequential loss of rhamnosyl and formaldehyde moieties. From the above analyses, this peak was deduced as quercetin 3-rhamnoside [38].

\subsubsection{Chlorogenic Acids}

Chlorogenic acid analogues are a type of caffeoyl quinic acids widely present in plants. In the UV spectrum, the maximum absorption at around $325 \mathrm{~nm}$ was due to the presence of caffeoyl group. In the $\mathrm{MS}^{2}$ experiment, the product ions at $\mathrm{m} / \mathrm{z} 163\left(\mathrm{C}_{9} \mathrm{H}_{6} \mathrm{O}_{3}\right)$ in positive mode and $191\left(\mathrm{C}_{7} \mathrm{H}_{12} \mathrm{O}_{6}\right)$ in negative mode were indicative for caffeic acid and quinic acid moieties. In this study, four isomers, namely, neochlorogenic acid (3), chlorogenic acid (6), cryptochlorogenic acid (7), and isochlorogenic acid (9) with identical formula of $\mathrm{C}_{16} \mathrm{H}_{18} \mathrm{O}_{9}$ were detected and tentatively characterized by their retention time on ODS column [39]. Peak 30 was assigned with the molecular formula of $\mathrm{C}_{25} \mathrm{H}_{24} \mathrm{O}_{12}$ with an additional quinoyl moiety compared to chlorogenic acid. This deduction was verified by the $\mathrm{MS}^{2}$ ions at $\mathrm{m} / z 353.0882$ $\left(\mathrm{C}_{16} \mathrm{H}_{18} \mathrm{O}_{9}\right)$ and $173.0401\left(\mathrm{C}_{7} \mathrm{H}_{10} \mathrm{O}_{5}\right)$ in negative mode. Thus, peak 30 was delineated as dicaffeoylquinic acid [40].

\subsubsection{Triterpenoids}

Peak 56 showing terminal absorption in UV spectrum was revealed with the molecular formula of $\mathrm{C}_{30} \mathrm{H}_{46} \mathrm{O}_{5}$. The abovementioned features were indicative for a triterpenoid. The $\mathrm{MS}^{2}$ fragments at $m / z 469\left(\mathrm{C}_{30} \mathrm{H}_{44} \mathrm{O}_{4}\right), 451\left(\mathrm{C}_{30} \mathrm{H}_{42} \mathrm{O}_{3}\right)$, 
and $423\left(\mathrm{C}_{29} \mathrm{H}_{42} \mathrm{O}_{2}\right)$ were in accordance with quinovic acid [41]. Peaks 49 and $\mathbf{5 2}$ were deduced to be diglycoside and triglycoside derivatives of quinovic acid by the additional two and three glycosyls which were verified by the sequential loss of $\mathrm{C}_{6} \mathrm{H}_{10} \mathrm{O}_{5}$ parts in the $\mathrm{MS}^{2}$ experiments. Thus, quinovic acid diglycoside and quinovic acid triglycoside were respectively determined [42].

\subsubsection{Other Compounds.}

Peak 1 was assigned as sucrose which was widely present in plants by the characteristic $[\mathrm{M}+\mathrm{K}]^{+}$ion at $\mathrm{m} / \mathrm{z}$

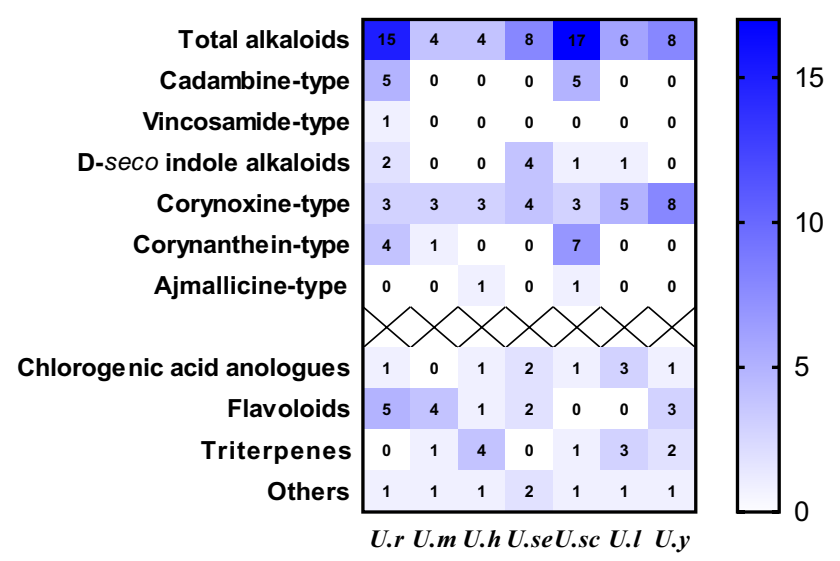

Fig. 2 Distribution of different types of compounds among seven Uncaria plants
381.0792. Peak 2 had a molecular formula of $\mathrm{C}_{16} \mathrm{H}_{24} \mathrm{O}_{10}$ showing $[\mathrm{M}+\mathrm{Na}]^{+}$ion at $\mathrm{m} / z 399.1258$ and $[\mathrm{M}-\mathrm{H}]^{-}$ion at $\mathrm{m} / \mathrm{z}$ 375.1301. In the $\mathrm{MS}^{2}$ experiment, the loss of glycosyl was verified by the ion at $m / z 215.0678\left(\mathrm{C}_{13} \mathrm{H}_{10} \mathrm{O}_{3}\right)$. Thus, this peak was illustrated as loganic acid, the biosynthetic precursor of indole alkaloids [43].

\subsection{Chemical Comparison}

As shown in Figs. 2 and 3, a temporal and spatial distribution of chemical constituents in seven Uncaria plants provided a visual overview of their difference. The chemical profiles of $U$. rhynchophylla and $U$. scandens were similar in terms of either indole alkaloids or other types of compounds. Indole alkaloids as the characteristic constituents were more prolific in $U$. rhynchophylla and $U$. scandens when comparing to other Uncaria plants. Cadambine-type and corynanthein-type alkaloids were the characteristic constituents in $U$. rhynchophylla and $U$. scandens, whereas corynoxine-type alkaloids were widely distributed in all the seven Uncaria plants. Besides alkaloids, flavonoids were another type of constituent in Uncaria plants, which were mainly distributed in $U$. rhynchophylla, U. macrophylla, and $U$. yunnanensis. For the triterpenoids, $U$. hirsuta and U. laevigata showed more prolific than other plants.

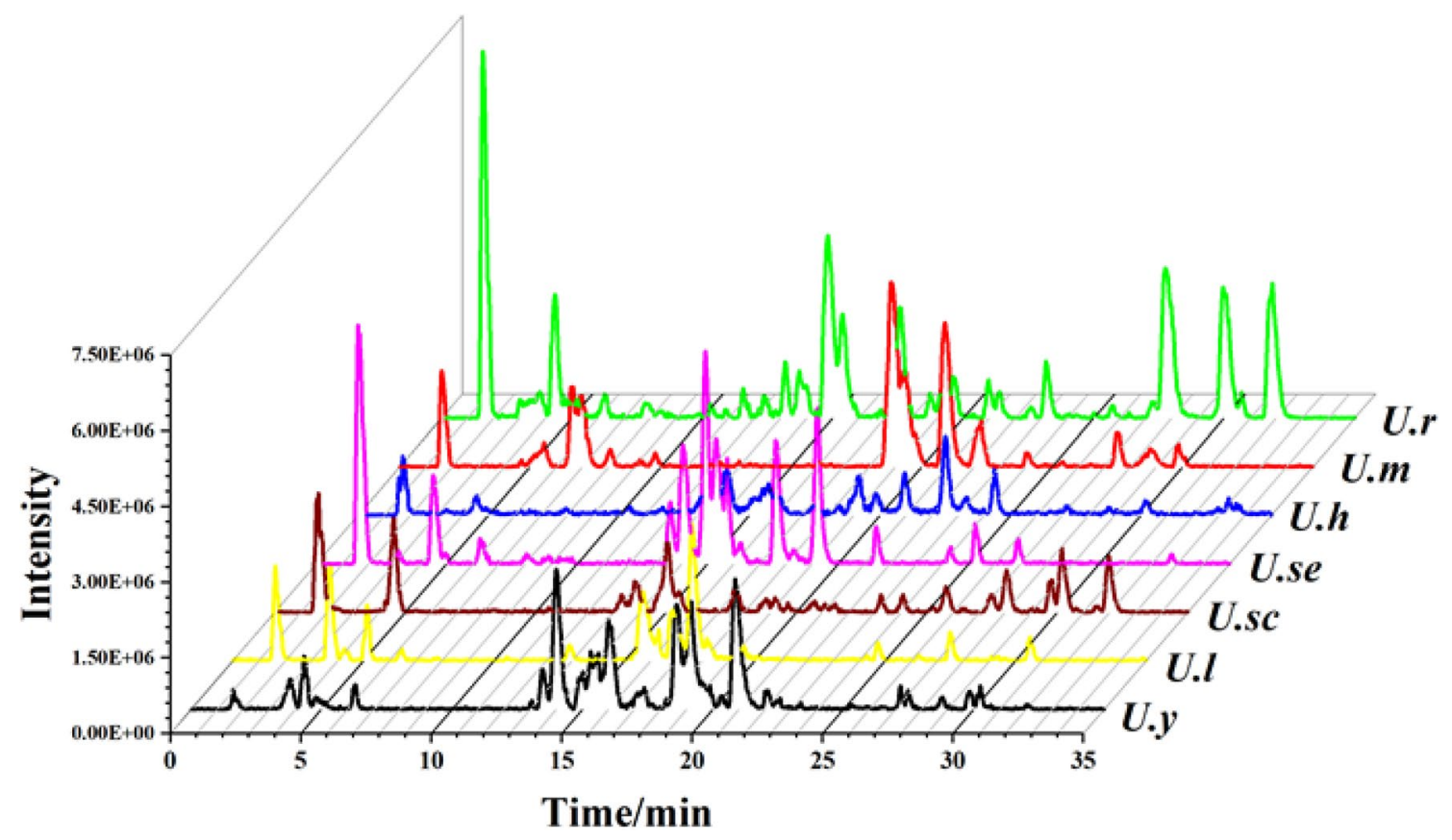

Fig. 3 Comparison of the BPCs (positive) of seven Uncaria plants 


\subsection{Biological Comparison on $\mathrm{MT}_{1 / 2}$ and $5-\mathrm{HT}_{1 \mathrm{~A} / 2 \mathrm{C}}$ Receptors}

Gou-Teng as a famous TCM are widely used for treating central nervous system (CNS) diseases in China. Therefore, four neurotransmitter receptors $\left(\mathrm{MT}_{1}, \mathrm{MT}_{2}, 5-\mathrm{HT}_{1 \mathrm{~A}}\right.$, and $5-\mathrm{HT}_{2 \mathrm{C}}$ ) that are closely related to $\mathrm{CNS}$ diseases were used to evaluate the psychiatric-related effects of Uncaria plants. As shown in Fig. 4, three plants, U. rhynchophylla, $U$. macrophylla, and $U$. yunnanensis showed obviously agnostic activity on all the four receptors. As a comparison, $U$. hirsuta, U. sessilifructus, and U. scandens were moderate, and $U$. laevigata was less active. Specifically, U. macrophylla displayed the most potent activity on $\mathrm{MT}_{1}$ receptor with an agonistic rate of $79.0 \%$, then followed with $U$. rhynchophylla (71.9\%), U. yunnanensis (41.5\%), and U. scandens $(26.1 \%)$, whereas $U$. hirsuta, U. sessilifructus, and $U$. laevigata were inactive. For $\mathrm{MT}_{2}$ receptor, $U$. yunnanensis possessed the highest agonistic rate of $91.2 \%$, and $U$. macrophylla and $U$. rhynchophylla exhibited moderate activity with agonistic rates of $54.2 \%$ and $44.8 \%$; however, $U$. scandens, U. sessilifructus, U. hirsuta, and U. laevigata were weak or inactive. Similar with the MT receptors, $U$. rhynchophylla, U. macrophylla, and U. yunnanensis possessed significant activity on $5-\mathrm{HT}_{1 \mathrm{~A}}$ and $5-\mathrm{HT}_{2 \mathrm{C}}$ receptors with agonistic rates higher that $60 \%$. Interestingly, $U$. scandens was revealed with the highest activity on $5-\mathrm{HT}_{2 \mathrm{C}}$ receptor $(82.7 \%)$, almost threefold higher than $5-\mathrm{HT}_{1 \mathrm{~A}}$, indicating the subtype selectivity.

\section{Conclusion}

Gou-Teng has long been recorded in ancient TCM books for the treatment of cardiovascular and mental disorders. According to the latest Chinese Pharmacopoeia, five Uncaria plants, U. rhynchophylla, U. macrophylla, U. sinensis, $U$. hirsuta, and $U$. sessilifructus are documented as the official resources of Gou-Teng. However, their chemical and biological difference as well as the discrepancy with other Uncaria plants are still disputed. Thus, the clinical application of Gou-Teng is confused owing to the prolific resources

\section{$\mathrm{MT}_{1}$ Receptor}

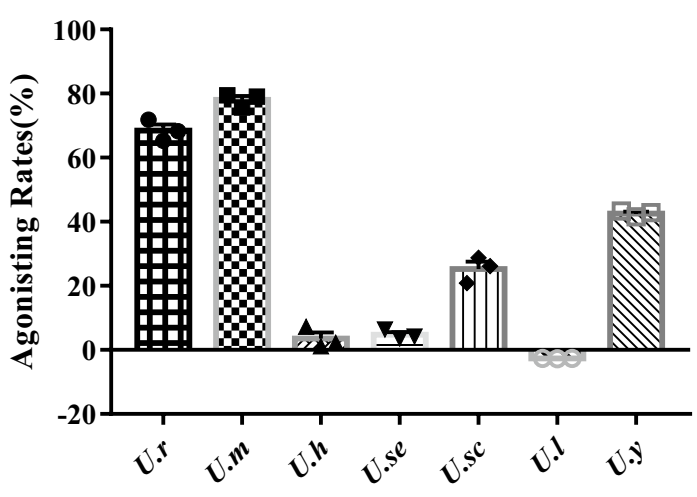

$5-\mathrm{HT}_{1 \mathrm{~A}}$ Receptor

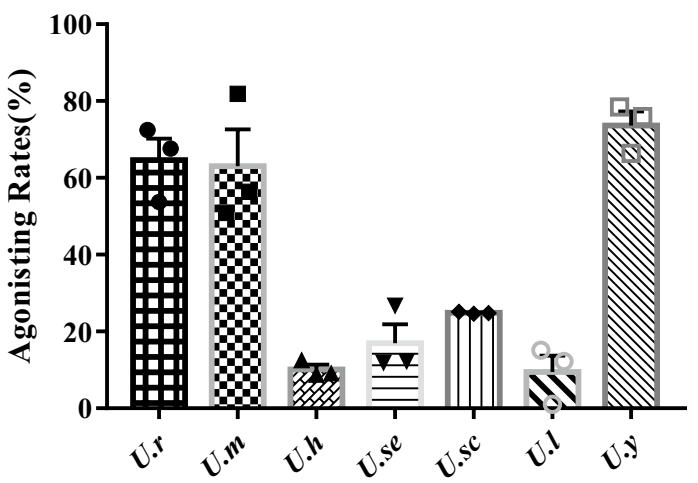

\section{$\mathrm{MT}_{2}$ Receptor}

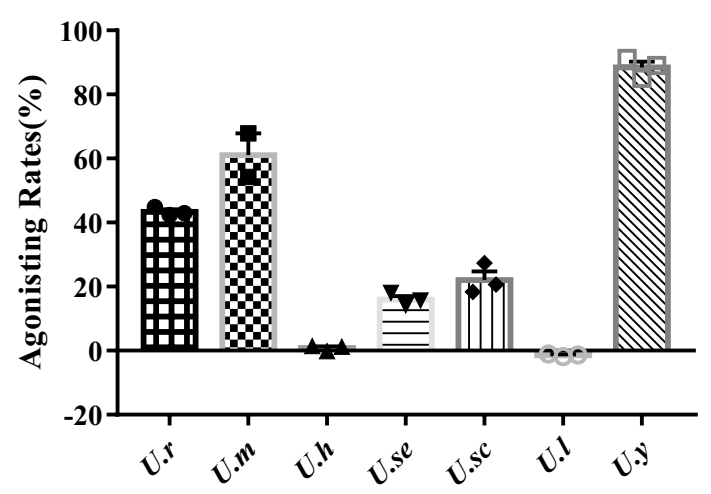

5-HT $2 \mathrm{C}$ Receptor

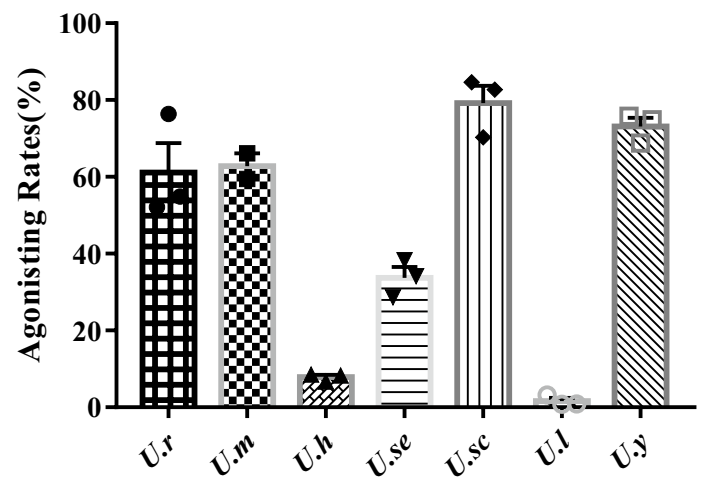

Fig. 4 Agonistic activities of seven Uncaria plants on $\mathrm{MT}_{1 / 2}$ and 5- $\mathrm{HT}_{1 \mathrm{~A} / 2 \mathrm{C}}$ receptors. The agonistic activities were expressed as $\mathrm{X} \pm \mathrm{SEM}$ $(n=3)$, which were obtained by comparing to the positive controls, melatonin (on MT receptors) and 5-hydroxytryptamine (on 5-HT receptors) 
and morphological similarity between different species. In this investigation, seven Uncaria species involving four official, $U$. rhynchophylla, U. macrophylla, U. hirsuta, and $U$. sessilifructus, and three local species, $U$. scandens, $U$. laevigata, and $U$. yunnanensis were extensively compared based on LCMS and bioassay in vitro. In total, 57 constituents including 35 indole alkaloids, ten flavonoids, five triterpenoids, five chlorogenic analogues, and two other compounds were characterized based on their MS/MS patterns and UV absorptions. Cadambine-type and corynantheintype alkaloids were exclusively present in $U$. rhynchophylla and $U$. scandens, whereas corynoxine-type alkaloids were commonly detected in all the seven Uncaria plants. Three Uncaria plants, $U$. rhynchophylla, U. macrophylla, and $U$. yunnanensis showed obviously agnostic activity on four receptors, suggesting their biological similarity regardless of the chemical difference. This investigation supported the synergistic effects of TCMs due to the complicated constituents and their complementarity in taking effects. This study provides valuable information for understanding the chemical and biological difference between different Uncaria plants and the "one-drug multi-source" theory.

\section{Experimental}

\subsection{LCMS Analyses}

LCMS analyses were performed on a Shimadzu UFLC/ MS-IT-TOF apparatus (Shimadzu, Kyoto, Japan) equipped with a Welch Ultimate XB-C ${ }_{18}$ column $(2.1 \times 100 \mathrm{~mm}$, i.d., $1.8 \mu \mathrm{m})$. The mobile phase for LCMS consisted of water $(0.05 \%$ formic acid, A) and acetonitrile $(0.05 \%$ formic acid, B) with the flow rate of $0.2 \mathrm{~mL} / \mathrm{min}$. A binary gradient elution was performed as follows: linear gradient $(\mathrm{B} \%)$ from 10 to $35 \%$ in $35 \mathrm{~min}$, and fast increased to $100 \%$ in one min and maintained for three min. Re-equilibration duration was five min between individual runs. The injection volume was $2 \mu \mathrm{L}$ for each LCMS analysis. The detailed MS parameters were set as previously reported [44]. The PDA profiles were recorded from 190 to $400 \mathrm{~nm}$. The Shimadzu Composition Formula Predictor was used to speculate the molecular formula.

\subsection{Plant Materials}

Plants of Uncaria rhynchophylla (Miq.) Miq. ex Havil. (No. 2,016,090,001), Uncaria macrophylla Wall. (No. 2,016,090,002), Uncaria hirsuta Havil. (No. 2,016,090,003), Uncaria sessilifructus Roxb. (No. 2,016,090,004), Uncaria scandens (Smith) Hutchins. (No. 2,016,090,005), Uncaria laevigata Wall. ex G. Don (No. 2,016,090,006), and Uncaria yunnanensis K. C. Hsia (No. 2,016,090,007) were collected from Xishuangbanna Dai Autonomous Prefecture of Yunnan Province in China in September 2016, and authenticated by Dr. Li-Gong Lei (Kunming Institute of Botany, CAS). Voucher specimens (No. 2,016,090,001-2,016,090,007) were deposited in the Laboratory of Antivirus and Natural Medicinal Chemistry, Kunming Institute of Botany, CAS. The hook-bearing stems were dried at room temperature and kept in amber glass flasks until extraction. The powder of each sample $(2.0 \mathrm{~g})$ was extracted with ethanol-water $(7: 3, v / v, 10 \mathrm{~mL})$ under ultrasonic for $30 \mathrm{~min}$. The extraction was filtered through a PTFE micro-porous filter $(0.22 \mu \mathrm{m}$, Jiangsu Hanbon Science \& Technology Co., Ltd.) into $2 \mathrm{~mL}$ screw cap vials prior to LCMS analyses.

\subsection{Agonistic Activities on $\mathrm{MT}_{1 / 2}$ and 5- $\mathrm{HT}_{1 \mathrm{~A} / 2 \mathrm{C}}$ Receptors}

Bioassay for agonistic activities on melatonin and 5-hydroxytryptamine receptors was performed in accordance with the previous reports [20, 45]. In brief, HEK293 cells stably expressing human melatonin ( $\mathrm{MT}_{1}$ and $\mathrm{MT}_{2}$ ) and 5-hydroxytryptamine $\left(5-\mathrm{HT}_{1 \mathrm{~A}}\right.$ and $5-\mathrm{HT}_{2 \mathrm{C}}$ ) receptors were maintained in DMEM containing 10\% FBS. Cells were seeded at a density of $4 \times 10^{4}$ cells/well in pre-matrigel-coated 96-well black wall/clear bottom plates. After overnight incubation at $37{ }^{\circ} \mathrm{C}$ with $5 \% \mathrm{CO}_{2}$, the cells were dyed with $100 \mu \mathrm{L}$ of HDB Wash Free Fluo- 8 Calcium Assay kit at $37^{\circ} \mathrm{C}$. An hour later, the cells were transferred into FlexStation3 Benchtop Multi-Mode Microplate Reader (Molecular Devices, Sunnyvale, California, United States) for bioassay. The raw data from time sequence recording were normalized as percentage responses to melatonin and 5-hydroxytryptamine as the positive controls, and analyzed to fit the four-parameter logistic equation to assess the agonistic rates.

\subsection{Statistical Analyses}

All experiments were carried out in triplicate. Data were expressed as mean \pm standard error of mean (Mean \pm SEM). Statistical analysis was performed using GraphPad Prism 7 (GraphPad Software Inc., San Diego, CA) and Origin 2018 (OriginLab Corporation, Wellesley Hills, MA) software.

Acknowledgements This work was financially supported by the National Natural Science Foundation of China (81573322), the Yunnan Wanren Project (YNWR-QNBJ-2018-061), the Youth Innovation Promotion Association, CAS (2013252), the Program of Yunling Scholarship, the Yunnan Science Fund for Excellent Young Scholars (2019FI017), and the Reserve Talents of Young and Middle-aged Academic and Technical Leaders in Yunnan Province.

\section{Compliance with Ethical Standards}

Conflict of interest The authors declare no conflict of interest. 
Open Access This article is licensed under a Creative Commons Attribution 4.0 International License, which permits use, sharing, adaptation, distribution and reproduction in any medium or format, as long as you give appropriate credit to the original author(s) and the source, provide a link to the Creative Commons licence, and indicate if changes were made. The images or other third party material in this article are included in the article's Creative Commons licence, unless indicated otherwise in a credit line to the material. If material is not included in the article's Creative Commons licence and your intended use is not permitted by statutory regulation or exceeds the permitted use, you will need to obtain permission directly from the copyright holder. To view a copy of this licence, visit http://creativecommons.org/licenses/by/4.0/.

\section{References}

1. Q. Zhang, J.J. Zhao, J. Xu, F. Feng, W. Qu, J. Ethnopharmacol. 173, 48-80 (2015)

2. M.E. Heitzman, C.C. Neto, E. Winiarz, A.J. Vaisberg, G.B. Hammond, Phytochemistry 66, 5-29 (2005)

3. A. Ndagijimana, X. Wang, G. Pan, F. Zhang, H. Feng, O. Olaleye, Fitoterapia 86, 35-47 (2013)

4. J.Y. Zhou, S.W. Zhou, Fitoterapia 83, 617-626 (2012)

5. K. Keplinger, G. Laus, M. Wurm, M.P. Dierich, H. Teppner, J. Ethnopharmacol. 64, 23-34 (1999)

6. J.G. Zhang, J.J. Chen, C.A. Geng, Chin. J. Chin. Mater. Med. 44, 685-695 (2019)

7. Chinese Pharmacopoeia Commission, Pharmacopoeia of the People's Republic of China, vol. 1 (China Medical Science Press, Beijing, 2015), p. 257

8. Y. Ogawa, Y. Fujii, R. Sugiyama, T. Konishi, J. Ethnopharmacol. 177, 19-27 (2016)

9. T. Itoh, Y. Shimada, K. Terasawa, Mech. Ageing. Dev. 111, 155173 (1999)

10. I. Sakakibara, S. Terabayashi, M. Kubo, M. Higuchi, Y. Komatsu, M. Okada, K. Taki, J. Kamei, Phytomedicine 6, 163-168 (1999)

11. L.C. Hsu, Y.J. Ko, H.Y. Cheng, C.W. Chang, Y.C. Lin, Y.H. Cheng, M.T. Hsieh, W.H. Peng, Evid. Based Complement. Altern. Med. 2012, 497302 (2012)

12. C.A. Geng, T.H. Yang, X.Y. Huang, Y.B. Ma, X.M. Zhang, J.J. Chen, J. Ethnopharmacol. 232, 39-46 (2019)

13. C. Von Gall, J.H. Stehle, D.R. Weaver, Cell. Tissue Res. 309, $151-162(2002)$

14. R. Hardeland, D.P. Cardinali, V. Srinivasan, D.W. Spence, G.M. Brown, S.R. Pandi-Perumal, Prog. Neurobiol. 93, 350-384 (2011)

15. J.D. McCorvy, B.L. Roth, Pharmacol. Ther. 150, 129-142 (2015)

16. F. Artigas, Pharmacol. Ther. 137, 119-131 (2013)

17. J.G. Zhang, C.A. Geng, X.Y. Huang, X.L. Chen, Y.B. Ma, X.M. Zhang, J.J. Chen, Eur. J. Mass Spectrom. 23, 11-21 (2017)

18. M. Chandel, M. Kumar, U. Sharma, B. Singh, S. Kaur, Comb. Chem. High. Throughput. Screen. 20, 760-772 (2017)

19. Y. Gai, H. Chen, C. Wu, F. Feng, Y. Wang, W. Liu, S. Wang, J. Sep. Sci. 36, 3723-3732 (2013)

20. J.G. Zhang, X.Y. Huang, Y.B. Ma, X.M. Zhang, J.J. Chen, C.A. Geng, J. Sep. Sci. 41, 1532-1538 (2018)
21. J. Qu, T. Gong, B. Ma, L. Zhang, Y. Kano, D. Yuan, Chem. Pharm. Bull. 60, 23-30 (2012)

22. D. Martins, C.V. Nunez, Molecules 20, 13422-13495 (2015)

23. C.L. Cardoso, I. Castro-Gamboa, D.H. Silva, M. Furlan, R.D. Epifanio, A.D. Pinto, C. de Moraes Rezende, J.A. Lima, V.D. Bolzani, J. Nat. Prod. 67, 1882-1885 (2004)

24. A. Itoh, T. Tanahashi, N. Nagakura, T. Nishi, Phytochemistry 62, 359-369 (2003)

25. J.H. Paul, A.R. Maxwell, W.F. Reynolds, J. Nat. Prod. 66, 752$754(2003)$

26. S. Wei, Z. Luo, S. Cui, J. Qiao, Z. Zhang, L. Zhang, J. Fu, X. Ma, Molecules 24, 175 (2019)

27. S. Xie, Y. Shi, Y. Wang, C. Wu, W. Liu, F. Feng, N. Xie, J. Pharm. Biomed. Anal. 81, 56-64 (2013)

28. T.J. Kim, J.H. Lee, J.J. Lee, J.Y. Yu, B.Y. Hwang, S.K. Ye, L. Shujuan, L. Gao, M.Y. Pyo, Y.P. Yun, Biol. Pharm. Bull. 31, 2073-2078 (2008)

29. X. Wei, L.P. Jiang, Y. Guo, A. Khan, Y.P. Liu, H.F. Yu, B. Wang, C.F. Ding, P.F. Zhu, Y.Y. Chen, Y.L. Zhao, Y.B. Chen, Y.F. Wang, X.D. Luo, Nat. Prod. Bioprospect. 7, 413-419 (2017)

30. T. Pengsuparp, B. Indra, O. Nakagawasai, T. Tadano, Y. Mimaki, Y. Sashida, Y. Ohizumi, K. Kisara, Eur. J. Pharmacol. 425, 211$218(2001)$

31. H.Q. Pan, W.Z. Yang, Y.B. Zhang, M. Yang, R.H. Feng, W.Y. Wu, D.A. Guo, Anal. Bioanal. Chem. 407, 6057-6070 (2015)

32. M. Hesse, Indolalkaloide in Tabellen, vol. 105 (Springer, Berlin, 1964)

33. B. Zhao, Y. Huang, Q. Chen, Q. Chen, H. Miao, S. Zhu, C. Zeng, Biomed. Chromatogr. 32, e4119 (2018)

34. S. Masumoto, S. Aoki, T. Miura, T. Shoji, Mol. Nutr. Food. Res. 62, e1700867 (2018)

35. S. Zhang, X. Liu, Z.L. Zhang, L. He, Z. Wang, G.S. Wang, Molecules 17, 13917-13922 (2012)

36. N. Lopez-Gutierrez, R. Romero-Gonzalez, P. Plaza-Bolanos, J.L. Martinez Vidal, A. Garrido Frenich, Food Chem. 173, 607-618 (2015)

37. A. Singh, S. Kumar, V. Bajpai, T.J. Reddy, K.B. Rameshkumar, B. Kumar, Rapid Commun. Mass Spectrom. 29, 1095-1106 (2015)

38. X.A. Yu, J. Teye Azietaku, J. Li, H. Wang, F. Zheng, J. Hao, Y.X. Chang, Evid. Based Complement. Altern. Med. 2018, 4964291 (2018)

39. Y. Zhao, C.A. Geng, Y.B. Ma, X.Y. Huang, H. Chen, T.W. Cao, K. He, H. Wang, X.M. Zhang, J.J. Chen, J. Ethnopharmacol. 156, 147-154 (2014)

40. Z. Wang, S. Wang, B. Qin, Biomed. Chromatogr. 31, e3811 (2017)

41. C. Pavei, S. Kaiser, S.G. Verza, G.L. Borre, G.G. Ortega, J. Pharm. Biomed. Anal. 62, 250-257 (2012)

42. P. Montoro, V. Carbone, D. de Quiroz, F. De Simone, C. Pizza, Phytochem. Anal. 15, 55-64 (2004)

43. W. Liu, Q. Song, Y. Cao, N. Xie, Z. Li, Y. Jiang, J. Zheng, P. Tu, Y. Song, J. Li, J. Pharm. Biomed. Anal. 162, 16-27 (2019)

44. C.A. Geng, H. Chen, X.L. Chen, X.M. Zhang, L.G. Lei, J.J. Chen, Int. J. Mass Spectrom. 361, 9-22 (2014)

45. C.A. Geng, X.Y. Huang, Y.B. Ma, B. Hou, T.Z. Li, X.M. Zhang, J.J. Chen, J. Nat. Prod. 80, 959-964 (2017) 